\title{
Influence of blast-induced ground vibrations on buried transmission pipelines
}

\author{
Siniša Stanković, Vinko Škrlec, Mario Dobrilović
}

\begin{abstract}
Drill and blast method is still most economical and efficient practice for different types of excavation. However, in vicinity of buried transmission pipelines, the vibrations must be held below recommended values. Influence of blast induced ground vibrations on buried pipelines has been described throughout three different projects. During the first project, oil pipeline has been partially open allowing extensive measurements directly on it. In this paper, only vibration monitoring data were analyzed and correlation equation between ground vibration and vibration on pipeline has been developed. Such equation is than used to predict vibration on the pipeline where direct measurements were not possible.
\end{abstract}

Keywords - blast-induced vibrations, charge weight per delay, transmission pipelines

\section{Introduction}

Explosive is well known energy effective solution for rock breaking in different working areas. However, blasting has its side effects, ground vibration, air blast, and fly-rock. The ground vibration usually needs the most attention. Scaling of distance or charge weight per delay is making the calculation of the ground vibration possible, when both distance and charge weight per delay vary. "The blast effects include a change in rock behavior having implications on the stability and integrity of structures." [1] Every new project including drilling and blasting works is a potential hazard for buried infrastructures. The different pipelines (oil, gas, etc.) due to possible huge environmental impact needs the most sensitive approach. "Damage" is defined as any type of failures leading to pressure or product loss [2]. Guideline values for vibration velocity to be used when evaluating the effects of short-term vibration on buried pipework are usually given by standard, in this case HRN DIN 4150 part 3 [3]. Several researches have been done on the subject, all giving some limiting criteria [4]. However, at small distances (about 5m), physical movement of rock blocks by explosive gases may be more of a problem than vibrations [5]. Furthermore, research has been done to relate ground vibration to pipeline stress [6,7]. Another type of research has been done in the field of low-density explosives. Using it to reduce blasting charge impact and damage to the surrounding rock mass, as well as seismic waves caused by the detonation $[8,9]$.

\section{The idea behind research}

Three different projects are described in this research. The first project is excavation by drilling and blasting method of right tunnel tube, near oil transmission pipeline, while left tunnel tube was operational.

Siniša Stanković, Vinko Škrlec, Mario Dobrilović

Faculty of Mining, Geology and Petroleum Engineering

Croatia
During this project the part of the oil pipeline has been opened and wide-range measurements were done. The idea was to get a correlation between ground vibration above pipeline and the vibration of the pipeline itself, and that to use it for the future projects in same or very similar geological conditions, where pipeline could not be opened. The literature shows that blast induced ground vibration values above pipeline will differ from pipeline vibration. Hence for the future projects, this new correlation could be used to modify the measurement results where measuring vibrations directly on the pipeline is not possible.

\section{Work sites and vibration monitoring instrument positioning}

Throughout the years, there were three projects with gas, oil or water supply pipeline in vicinity. They are arranged chronologically. The geology for all three is consisted mainly of limestone. Limiting criteria for vibration velocity when evaluating the effects of short-term vibration on buried pipeline is usually given by standard. Guideline values for vibration velocity used were taken from standard HRN DIN 4150 part 3 [3] and described in Table I.

TABLE I. GUIDELINE VALUES FOR VIBRATION VELOCITY TO BE USED WHEN EVALUATING THE EFFECTS OF SHORT-TERM VIBRATION ON BURIED PIPEWORK AS PER HRN DIN 4150 PART 3

\begin{tabular}{|c|l|c|}
\hline Line & \multicolumn{1}{|c|}{ Pipe material } & $\begin{array}{c}\text { Guideline values for } \\
\text { velocity measured on the } \\
\text { pipe, } \boldsymbol{v}_{\boldsymbol{i}} \text { in } \mathbf{~ m m} / \mathbf{s}\end{array}$ \\
\hline 1 & Steel (including welded pipes) & 100 \\
\hline 2 & $\begin{array}{l}\text { Clay, concrete, reinforced } \\
\text { concrete, prestressed concrete, } \\
\text { metal (with or without flanfe) }\end{array}$ & 80 \\
\hline 3 & Masonry, plastic & 50 \\
\hline
\end{tabular}

The first project was tunnel "Veliki Gložac", in 2005., (Figure 1), where extensive measurements have been done [10]. For that project oil pipeline has been partially opened allowing different types of measurement to be done. In this paper as mentioned, only blast induced vibration monitoring will be discussed. The monitoring instrument were positioned one directly on the pipeline and second on the ground above pipeline, near opening. Complete measurement setup on the oil transmission pipeline is presented in Figure 2, while position of the pipeline in relation to excavating tunnel is shown in Figure 3.

In the 2006., second project, blasting works for extending area near football stadium was in town Višnjan [11]. 


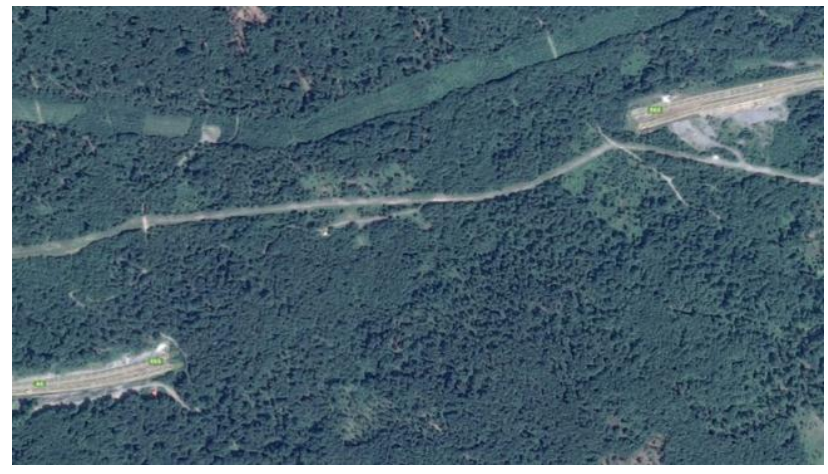

Figure 1. Tunnel "Veliki Gložac" with oil pipeline passing over it
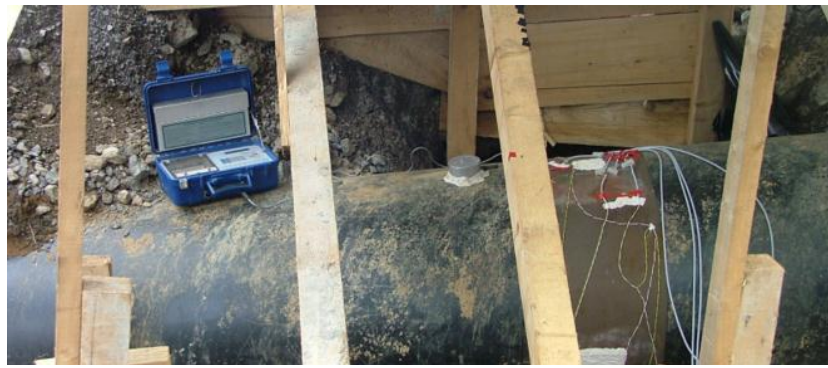

Figure 2. Measurement setup on the oil transmission pipeline [10]

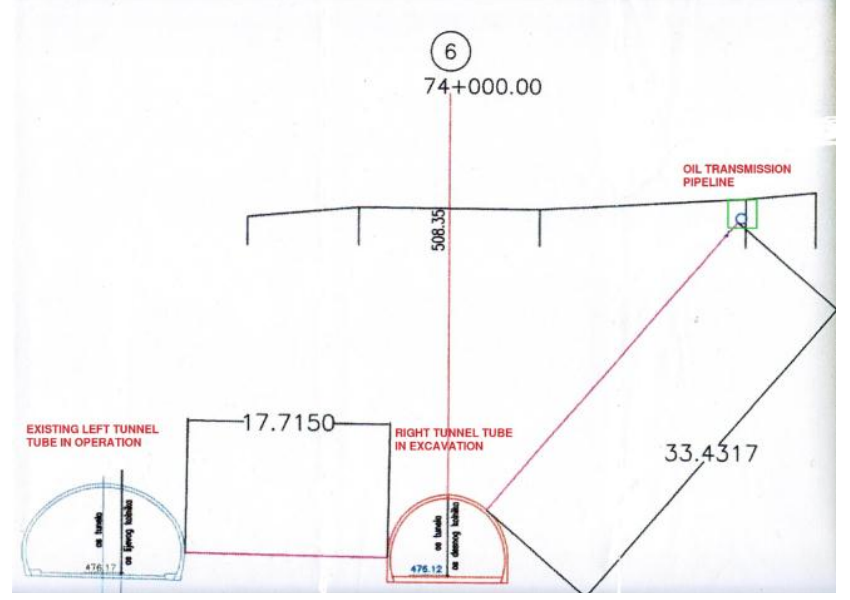

Figure 3. Position of the pipeline in relation to excavating tunnel at chainage $74+000,00$ [10]

The main water supply tank was North-west of blast area and water transmission pipeline was passing from water supply tank towards South-West. Since opening of the pipeline, like in the first project was not possible, the vibration monitoring instruments were positioned on the ground along the pipeline. The first instrument was placed closer to the blast while second one has been placed near the water tank (Figure 4).

The third project was quarry "Veprštak", in 2014 [12]. The gas transmission pipeline is placed on South-East side of the quarry near state road. Since like with the second project, opening of the pipeline was not possible, another measurement setting has been tried. Two measurement points were placed between quarry and gas transmission pipeline, in a way that each measurement point had two geophones, one on the ground and one in the borehole on the

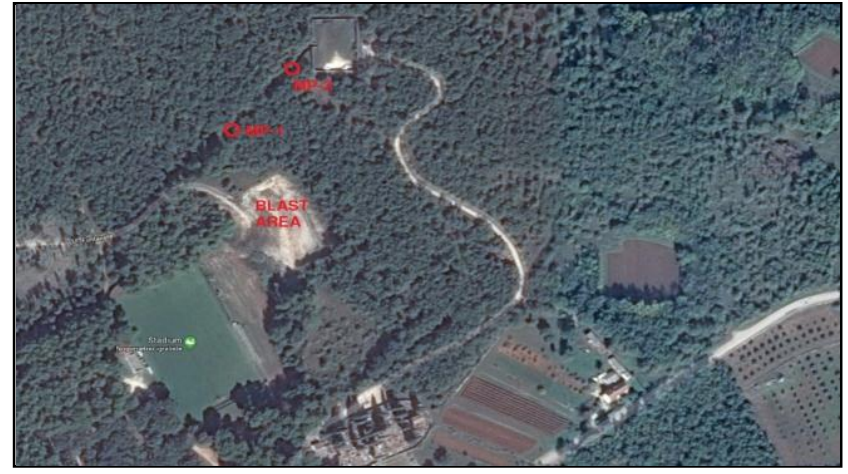

depth of $1,5 \mathrm{~m}$, the same depth as the gas pipeline is buried
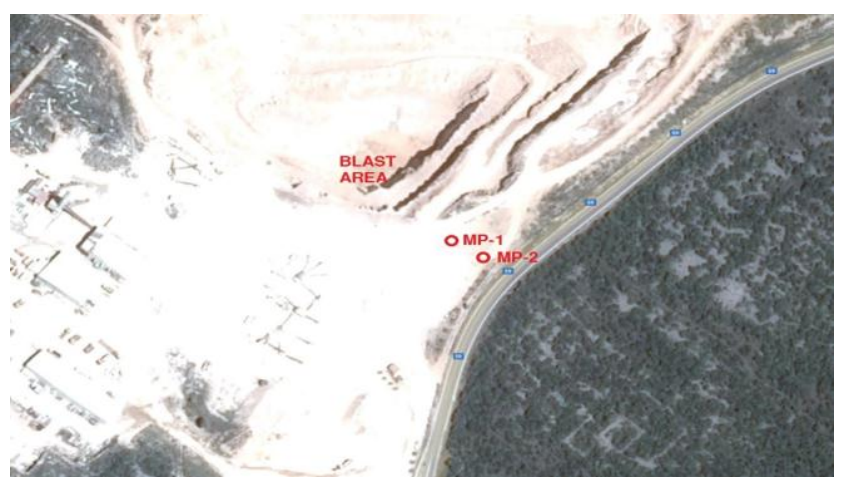

(Figure 5).

Figure 4. Position of the monitoring points in relation to the blast area

Figure 5. Position of the monitoring points in relation to the blast area

The vibration monitoring instruments used for the vibration measurements were INSTANTEL Pro 4, INSTANTEL BlastMate Series II and III, INSTANTEL Minimate, INSTANTEL Minimate Blaster and INSTANTEL Minimate plus. Obtained field measurement data are downloaded and processed using the Instantel software "Blastware". As a result, a measurement record for each measuring point is created.

\section{Results and analysis}

From created reports or directly from the specified computer program, values of recorded ground vibration velocity and distance from the blast are collected. For the Project, vibration monitoring of oil pipeline during excavation of right tube of tunnel "Veliki Gložac", measurements have been done during 3 blasts and data [10] presented in Table II.

TABLE II. PEAK VECTOR SUM MEASURED ON PIPELINE, GROUND ABOVE PIPELINE AND DISTANCE FROM BLAST

\begin{tabular}{|c|c|c|c|}
\hline Tunnel chainage & $\begin{array}{c}\boldsymbol{P V} \boldsymbol{S}_{\mathbf{p}} \\
\mathbf{( m m} / \mathbf{s})\end{array}$ & $\begin{array}{c}\boldsymbol{P V} \boldsymbol{S}_{\mathbf{g}} \\
\mathbf{( m m} / \mathbf{s})\end{array}$ & Distance (m) \\
\hline $74+072,6$ & 1,29 & 2,81 & 79,4 \\
\hline $74+041,5$ & 4,4 & 6,33 & 55,6 \\
\hline $74+020,0$ & 5,87 & 7,25 & 46,6 \\
\hline
\end{tabular}


Proc. of the Seventh Intl. Conf. on Advances in Civil, Structural and Mechanical Engineering - CSM 2018 Copyright (C) Institute of Research Engineers and Doctors, USA .All rights reserved.

ISBN: 978-1-63248-163-4 DOI: 10.15224/978-1-63248-163-4-20

Importing measured data into graphical presentation, the correlation between Peek Vector Sum measured on pipeline and on the ground above it is calculated (Figure 6).

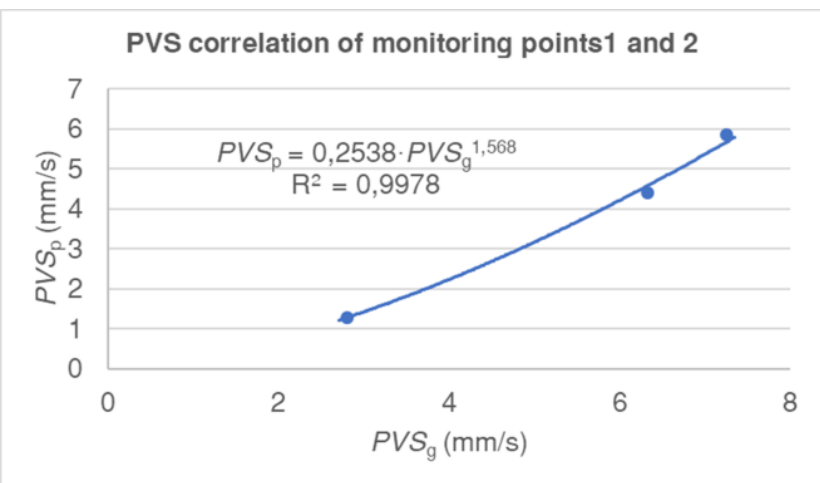

Figure 6. Correlation between Peak Vector Sum measured on pipeline (MP-1) and on the ground above pipeline (MP-2)

Developed correlation equation between Peak Vector Sum measured on pipeline (MP-1) and on the ground above pipeline (MP-2) is as follows:

$$
\text { PVS }_{p}=0,2538 \cdot \text { PVS }_{q}{ }_{q}^{1,568}
$$

where:

$P V S_{\mathrm{p}}$ - Peak Vector Sum measured on pipeline $(\mathrm{mm} / \mathrm{s})$

$P V S_{\mathrm{g}}$ - Peak Vector Sum measured on the ground above pipeline $(\mathrm{mm} / \mathrm{s})$

Using this equation in other two projects enabled prediction of pipeline vibration when direct measurements could not be taken.

The measurement data [11] from the second project, extending area near football field in town Višnjan, were taken from two measurement points positioned on the ground directly above water transmission pipeline (Table III).

TABLE III PEAK VECTOR SUM AND DISTANCES FOR MONITORING POINTS ON THE GROUND DIRECTLY ABOVE PIPELINE (MP-1) AND IN FRONT OF WATER TANK (MP-2)

\begin{tabular}{|c|c|c|c|c|}
\hline \multirow{2}{*}{ Blast area } & \multicolumn{2}{|c|}{ PVS (mm/s) } & \multicolumn{2}{c|}{ Distance (m) } \\
\cline { 2 - 5 } & MP-1 & MP-2 & MP-1 & MP-2 \\
\hline 1 & 42,7 & 9,22 & 50 & 94 \\
\hline
\end{tabular}

The first monitoring point (MP-1) has been positioned closer to the blast area, while second one (MP-2) near main water supply tank (Figure 7).

The attenuation equation calculated from measured values of ground vibration velocity and distance is:

$$
\text { PVS }_{q}=48391 \cdot q^{2,4282}
$$

where:

$\mathrm{q}$ - Scaled charge weight per delay $\left(\mathrm{kg}^{1 / 3} / \mathrm{m}\right)$

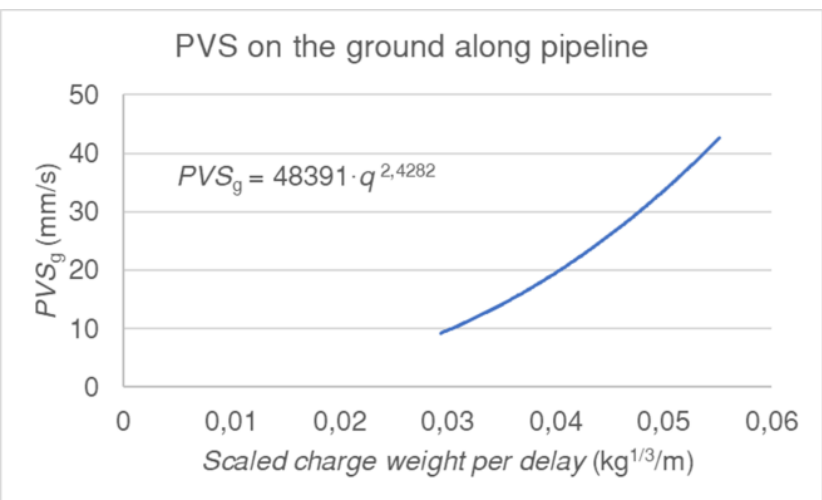

Figure 7. Peak Vector Sum and scaled charge weight per delay for monitoring points on the ground directly above pipeline, closer to the blast (MP-1) and in front of water tank (MP-2)

To predict vibrations on the pipeline, the measured data from measurement points MP-1 and MP-2 were modified using correlation equation (1). The attenuation equation calculated with modified data presents prediction of vibration on the water transmission pipeline for the second project:

$$
\text { PVS }_{p}=5626071 \cdot q^{3,8073}
$$

For the third project, Quarry "Veprštak", two measurement points were positioned between quarry and gas transmission pipeline, in a way that on each position two geophones were installed, one on the ground and one in the borehole on the depth of $1,5 \mathrm{~m}$, the same depth as the gas pipeline is buried. The measured vibrations and distances [12] from blast area are shown in Table IV.

TABLE IV. PEAK VECTOR SUM AND DISTANCES FOR MONITORING POINTS ON THE GROUND AND IN THE BOREHOLES

\begin{tabular}{|c|c|c|c|c|}
\hline \multirow{2}{*}{ Geophone position } & \multicolumn{2}{|c|}{$P V S$ (mm/s) } & \multicolumn{2}{c|}{ Distance (m) } \\
\cline { 2 - 5 } & MP-1 & MP-2 & MP-1 & MP-2 \\
\hline On the ground & 18,2 & 12,8 & 79 & 89 \\
\hline In the borehole & 9,54 & 10,2 & 79 & 89 \\
\hline
\end{tabular}

Measurements from this project did not give a satisfactory result. Although positions have not been directly above pipeline, the values measured on the ground, due to their higher values, were taken as valid for further calculations and were imported into graphical presentation (Figure 8).

The attenuation equation calculated from measured values of ground vibration velocity and distance is:

$$
P V S_{R}=110910 \cdot q^{29591}
$$


Proc. of the Seventh Intl. Conf. on Advances in Civil, Structural and Mechanical Engineering - CSM 2018

Copyright (C) Institute of Research Engineers and Doctors, USA .All rights reserved.

ISBN: 978-1-63248-163-4 DOI: 10.15224/978-1-63248-163-4-20

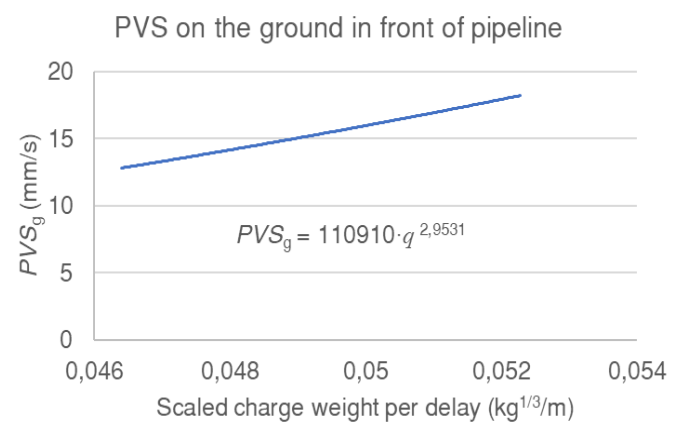

Figure 8. Peak Vector Sum and scaled charge weight per delay monitoring points on the ground in front of the pipeline

Again, to predict vibrations on the pipeline, the measured data from measurement points MP-1 and MP-2 were modified using correlation equation (1). The attenuation equation calculated with modified data presents prediction of vibration on the gas transmission pipeline for the third project:

PVS $_{p}=20654037 \cdot q^{4,6305}$

From equations (3) and (5), the maximum charge weight per delay is calculated in correlation to distance for second and third project respectfully.

\section{v. Conclusion}

The results show that even if measurements cannot be done on the transmission pipelines itself, prediction of pipeline vibration can be done indirectly, using the correlation equation (1). Undoubtedly, the equation used in this research will give usable results only in same or very similar geological conditions. For different type of rock, different correlation should be calculated and used.

\section{References}

[1] Kumar R, Choudhury D, Bhargava K. Determination of blast-induced ground vibration equations for rocks using mechanical and geological properties. J Rock Mech Geotech Eng 2016;8:341-9. doi:10.1016/j.jrmge.2015.10.009.

[2] Siskind BDE, Stagg MS, Wiegand JE, Schulz DL. Surface Mine Blasting near pressurised transmission pipelines 1995.

[3] Croatian Standards Institute. DIN 4150 Vibracije u građevinama -- 3. dio: Djelovanje na konstrukcije. Zagreb: Croatian Standards Institute; 2011.

[4] Heilig J, McKenzie C. Prevention of Damage to Buried Pipelines when Blasting an Adjacent Trench n.d.

[5] Dowding CH. Blast vibration monitoring and control. 1985.

[6] American Lifelines Aliance. Guidelines for the design of buried steel pipe 2001.

[7] Clark DA, Manager R. Relationships between pipe stress, ground particle velocity and scale factors in blasting dolomite 2000:257-68.

[8] Stanković S, Dobrilović M, Škrlec V, Bohanek V. Explosives with Addition of Organic Waste. NEW TRENDS Res. Energ. Mater. 2017, 2017, p. 1025-31.
[9] Stanković S, Škrlec V, Dobrilović M, Bohanek V. Velocity of detonation of AN base blasting agent with addition of hay and recycled rubber. NEW TRENDS Res. Energ. Mater. 2018, 2018, p. 1042-50.

[10] Ester Z, Kujundžić T, Dobrilović M. Mjerenja deformacija i proračun naprezanja na naftovodu prilikom iskopa desne cijevi tunela Veliki Gložac miniranjem. 2005.

[11] Ester Z, Dobrilović M. Elaborat mjerenja seizmičkih efekata miniranja i proračun dozvoljenih količina eksploziva pri proširenju nogometnog igrališta u Višnjanu. 2006.

[12] Dobrilović M, Bohanek V. Elaborat mjerenja seizmičkih utjecaja probnog miniranja na eksploatacijskom polju tehničko-građevnog kamena Veprštak, 31.07.2014. 2014 